\title{
Inverted appendix: Computed tomographic colonography diagnosis in a patient and lesson learned
}

\begin{abstract}
Author:
Joel Bortz ${ }^{1}$

Affiliation:

${ }^{1}$ LSG Imaging, Los Angeles, United States of America

\section{Correspondence to:}

Joel Bortz

Email:

joelbortzmd@gmail.com

Postal address:

13031 Villosa Place,

Apartment 141, Playa Vista,

California 90094, United

States of America

Dates:

Received: 03 Nov. 2014

Accepted: 04 June 2015

Published: 14 Aug. 2015

How to cite this article: Bortz J. Inverted appendix Computed tomographic colonography diagnosis in a patient and lesson learned. S Afr J Rad. 2015;19(1); Art. \#748, 4 pages. http://dx.doi. org/10.4102/sajr.v19i1.748
\end{abstract}

\section{Copyright:}

(C) 2015. The Authors.

Licensee: AOSIS

OpenJournals. This work is licensed under the Creative Commons Attribution

License.
Read online:

Scan this QR code with your smart phone or mobile device to read online.
The role of computed tomographic colonography in the diagnosis of an inverted appendix is described in an adult woman, with Mayer-Rokitansky-Küster-Hauser syndrome, who underwent a laparotomy during her childhood for severe abdominal pain. According to the patient, both a hysterectomy and an incidental appendectomy were performed.

\section{Introduction}

This report underscores the importance for radiologists to consider appendiceal inversion after appendectomy by any method when interpreting computed tomography colonography (CTC) images. Such awareness could reduce unnecessary interventions, such as colonoscopy.

\section{Case report}

A screening CTC was performed in 2012 on a 53-year-old asymptomatic woman who reported a hysterectomy and an appendectomy as part of her surgical history. The significant finding at CTC was a $5 \mathrm{~cm}$ linear structure arising from the appendiceal orifice in the caecal pole (Figure 1a). The structure projected into the colonic lumen on the prone study (Figures 1b-1c) but changed shape in the supine position (Figures $1 \mathrm{~d}-1 \mathrm{e}$ ). The translucent display showed high-attenuation tissue interspersed with areas of fat (Figure 1f). The appearance was that of an intact inverted appendix but, with the patient's recall of an appendectomy, a pedunculated polyp was considered. The remainder of the colon was normal.

Upon further questioning following the CTC, the patient, whose childhood medical and surgical records were not available, provided an articulate verbal report of her surgical history. She recalled that at the age of 15 years she developed acute lower abdominal pain without vaginal bleeding which necessitated an emergency laparotomy. According to the patient, the intra-operative findings included haematometra within a hypoplastic uterus and she was diagnosed with MayerRokitansky-Küster-Hauser (MRKH) syndrome. The patient was certain that the surgeon had informed her that both a hysterectomy and an appendectomy were performed during the surgery.

A same-day optical colonoscopy was performed which confirmed the presence of a $5 \mathrm{~cm}$ elongated structure compatible with an inverted appendix (Figure 2). Histological analysis confirmed normal mucosa with numerous small benign lymphoid aggregates of colonic mucosa. She was advised to undergo CTC screening every 5 years.

\section{Discussion}

The vermiform appendix is part of the caecum. Its length varies from $2.5 \mathrm{~cm}$ to $33 \mathrm{~cm} \cdot{ }^{1,2}$ Its average length is between $5 \mathrm{~cm}$ and $10 \mathrm{~cm}$ and its base is usually situated $2 \mathrm{~cm}$ below the ileo-caecal valve. Its intra-abdominal position may vary widely, depending on the peritoneal fold which represents the mesentery of the appendix. ${ }^{1}$ The appendix in this case report was of average length, namely $5 \mathrm{~cm}$.

Appendectomy for acute appendicitis remains one of the most frequently performed surgical procedures. ${ }^{3,4}$ From the patient's recall, she underwent a simple appendectomy at the time of abdominal surgery to prevent the risk of future acute appendicitis. ${ }^{4,5}$ According to her, the procedure was performed when she had a hysterectomy at the age of 15 years, at which stage Mayer-Rokitansky-Küster-Hauser syndrome, belonging to class 1 Müllerian duct anomalies, ${ }^{6}$ was diagnosed. Historically, incidental appendectomy was performed mainly during open cholecystectomy and gynaecological operations. ${ }^{4,5}$ 

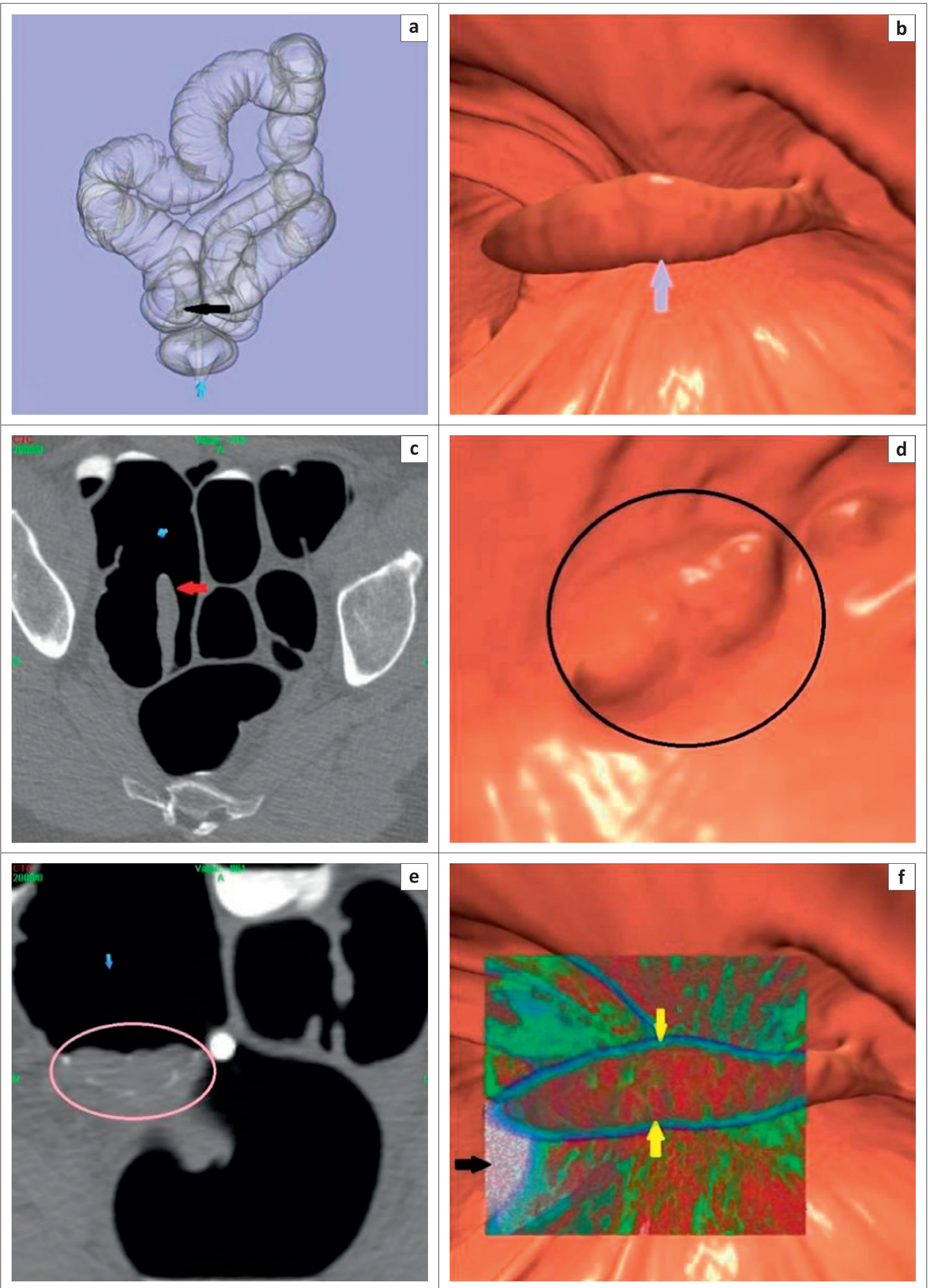

FIGURE 1: Prone air contrast colon map (a) shows an elongated structure (arrow). The prone 3D image (1b) shows the intact vertical appendix (arrow). The 2D prone axial view (1c) shows the vertical appendix (arrow). The 3D supine view (1d) shows the appendix (circled) surrounded by barium. The 2D supine view (1e) shows the appendix at the base of the caecal pole (circled). The prone translucent display (1f) shows the appendix (yellow arrows) with a small pool of barium at the tip (black arrow). 


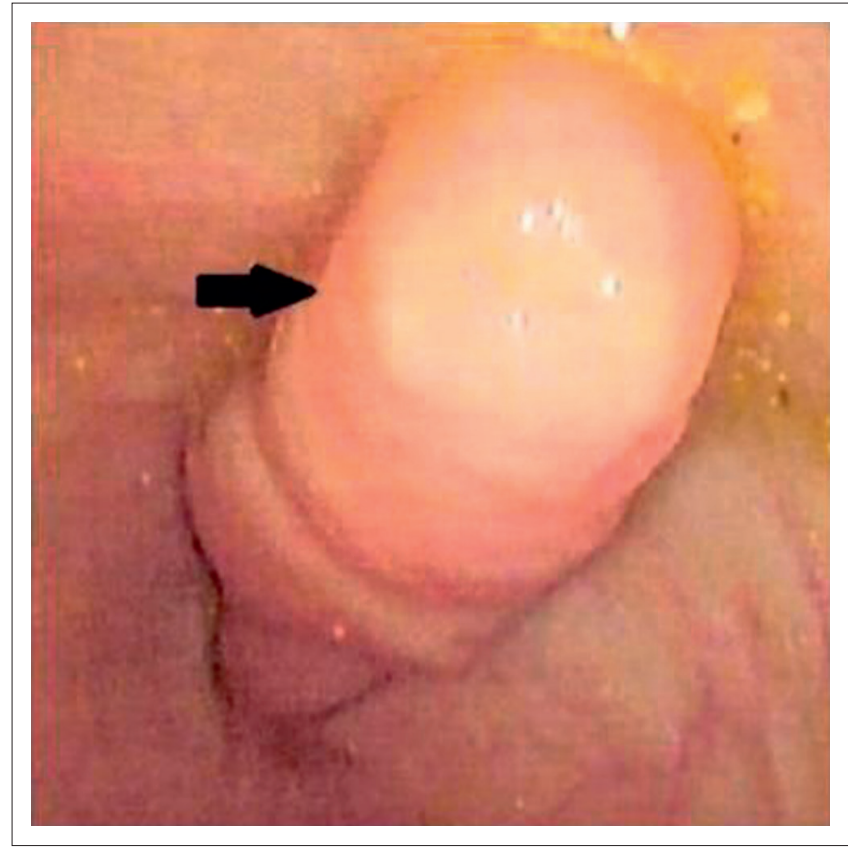

FIGURE 2: Digital photograph via optical colonoscopy, performed on the same day as the computed tomographic colonography, confirms an intact $5 \mathrm{~cm}$ appendix (arrow).

A full length appendix was noted during the CTC study which indicated that surgical resection of the appendix had not taken place (see Figures 1a-1c). The CTC images favoured a simple inversion appendectomy as the most likely procedure. Variations of this type of surgery would include inversion-ligation appendectomy, as well as appendectomy with stump inversion. ${ }^{3,7,8,9}$ Simple inversion appendectomy comprises ligation and division of the mesoappendix, full length inversion into the caecum and a seromuscular pursestring suture placed around the base of the appendix..$^{9,10}$ With simple inversion or inversion ligation, $31 \%$ of the appendices disappear and $69 \%$ remain visible, floating in the caecal lumen. ${ }^{8}$ The shape of the appendix may alter with postural change, ${ }^{1}$ as shown in Figures $1 \mathrm{~b}-1 \mathrm{e}$ in the present report.

Figures 1a-1c depict an inverted appendix in the caecal lumen. Simple inversion ${ }^{3}$ involves devascularisation of the appendix through ligation and cutting of the mesoappendix.9,10 An alternative technique, known as inversion-ligation, has also been employed which eliminates most of the appendix. The last $2 \mathrm{~mm}-4 \mathrm{~mm}$ of the appendix near the base is kept from protruding from the caecal wall. Using absorbable suture material, the stump is tied and the appendix base is buried by a purse-string suture. This technique devascularises the appendix which causes it to necrose; it then becomes detached and may appear in the stool within a few days postsurgery. ${ }^{9,10}$

Incidental appendectomy comprises removal of the appendix at the time of surgery for other unrelated conditions. ${ }^{11}$ Chalya and Mchembe $^{12}$ showed that simple ligation was as good as and probably better than inversion of the appendiceal stump. Pathological inversion should not be confused with therapeutic inversion. Pathological inversion may be secondary to appendiceal pathology, such as benign adenomas, malignant tumours, ${ }^{13}$ mucocele or appendiceal endometriosis, ${ }^{14}$ and may result in appendiceal intussusception. ${ }^{2}$

Despite the appendix in the present patient having apparently been inverted 38 years previously, it appeared intact and was of average length. A pedunculated polyp was considered in the differential diagnosis, but excluded as no definitive head was noted during the CTC examination. A 3D diagnostic translucent display (Figure 1f) was used at it provides a semitransparent view in different colours beneath the surface..$^{15}$ The software's different colour attenuation values are: red indicates soft tissue; white indicates high attenuation values, such as barium; green indicates negative values in the fat attenuation range; and blue indicates negative values, such as air.

Radiologists should be aware of appendiceal inversion after appendectomy by any method; this awareness might possibly reduce unnecessary interventions, such as optical colonoscopy. ${ }^{11}$ In addition, radiologists need to consider the different forms of appendectomy performed prior to the laparoscopic approach ${ }^{4,12}$ because the procedure might have been of the inversion variety as opposed to surgical removal. Asymptomatic appendiceal intussusception should be included in the differential diagnosis of a suspected inverted appendix. ${ }^{2}$

\section{Conclusion}

In the present report, the patient's recall of an appendectomy caused confusion during a screening CTC examination. The diagnosis of an inverted appendix using CTC should not present a diagnostic dilemma if the radiologist remembers that a history of an appendectomy might not necessarily equate with complete removal of the appendix. When radiologists encounter CTC findings similar to those discussed in the present report, they should ascertain whether the surgery was performed at a time when appendiceal inversion was common practice. ${ }^{7}$

\section{Acknowledgements}

Dr Marc Harwitt is thanked for providing the optical colonoscopy digital photograph.

\section{Competing interests}

The author declares that he has no financial or personal relationships which may have inappropriately influenced him in writing this article.

\section{References}

1. Ahmed I, Asgeirson K, Beckingham I, Lobo D. The position of the vermiform appendix at laparoscopy. Surg Radiol Anat. 2007;29:165-168. http://dx.doi. org/10.1007/s00276-007-0182-8

2. Varsamis N, Pouggouras $\mathrm{K}$, Salveridis $\mathrm{N}$, et al. Appendiceal intussusception. In: Lule G, editor. Current concepts in colonic disorders. c2012 [cited 2015 May 19]. Available from: http://www.intechopen.com/books/current-concepts-in-colonicdisorders/appendicealintussusception

3. Lilly JR, Randolph JG. Total inversion of the appendix: Experience with appendectomy in children. J Pediatr Surg. 1968;3:357-363. http://dx.doi.org/ 10.1016/0022-3468(68)90341-2 
4. Neulander EZ, Hawke CK, Solowa MS. Incidental appendectomy during radical cystectomy: An interdepartmental survey and review of the literature. Urology. cystectomy: An interdepartmental survey and review of the literature.

5. Pearce $C$, Torres $C$, Stallings $S$, et al. Elective appendectomy at the time of cesarean delivery: A randomized controlled trial. Am J Obstet Gynecol. 2008;199:491.e1-e5. http://dx.doi.org/10.1016/j.ajog.2008.03.063

6. Strübbe EH, Willemsen WN, Lemmens JA, Thijn CJ, Rolland R. Mayer-RokitanskyKüster-Hauser syndrome: Distinction between two forms based on excretory urographic, sonographic, and laparoscopic findings. AJR. 1993;160:331-334. http://dx.doi.org/10.2214/ajr.160.2.8424345

7. Prout JM, Taylor AJ, Pickhardt PJ. Inverted appendiceal stumps simulating pedunculated polyps on screening CT colonography. AJR. 2006;186:535-538. http://dx.doi.org/10.2214/ajr.04.1791

8. Almasad JK, Daoud FS. Long-term outcome of simple inversion of the appendix as an alternative to incidental appendectomy. Ann Saudi Med. 2008 [cited 2014 Oct 20 ];28:179-182. Available from: http://applications.emro.who.int/imemrf/ Ann_Saudi_Med/2008_28_3_179.pdf? origin=publication_detail

9. Bishop HC, Filston $\mathrm{H}$. An inversion-ligation technique for incidental appendectomy J Pediatr Surg. 1973;8:889-892. http://dx.doi.org/10.1016/0022-3468(73)90006-7
10. Johnson EK, Arcila M, Steele SR. Appendiceal inversion: A diagnostic and therapeutic dilemma. JSLS. 2009 [cited 2014 Oct 20 ];13:92-95. Available from: http://www.ncbi. nlm.nih.gov/pmc/articles/PMC3015910/

11. Snyder TE, Selanders JR. Incidental appendectomy - Yes or No? A retrospective case study and review of the literature. Infect Dis Obstet Gynecol. 1998;6:30-37. http://dx.doi.org/10.1155/S1064744998000076

12. Chalya PL, Mchembe M. Is invagination of appendicular stump in appendectomy necessary? A prospective randomised clinical study. East Cent Afri J Surg. 2012 [cited 2014 Oct 20];17:85-89. Available from: http://www.ajol.info/index.php/ ecajs/article/view/76500

13. Siddiqui G, Lipka S, Freedman L, et al. Mucinous adenocarcinoma of the appendix presenting as intussusception in 27 year old female. J Gastrointest Oncol. 2012 [cited 20 October 2014 ];3:369-372. Available from: http://www.ncbi.nlm.nih. gov/pmc/articles/PMC3492470/

14. Soylu L, Aydin O, Aydin S, Özcay N. Invagination of the appendix due to endometrioses presenting as acute appendicitis. Ulusal Cer Derg. 2014 [cited 2014 Oct 2014 ];30:106-108. Available from: http://www.ulusalcerrahidergisi.org

15. Pickhardt PJ, Kim, DH. CT colonography: Principles and practice of virtual colonoscopy. Philadelphia: Saunders, 2009; p. 224-225. 